\title{
HUBUNGAN PENGETAHAN GIZI DENGAN ASUPAN ENERGI, PROTEIN, PHOSPHOR, DAN KALIUM PASIEN PENYAKIT GINJAL KRONIK DENGAN HEMODIALISIS RUTIN DI RSUD TUGUREJO SEMARANG
}

\author{
Tika Yeni Rachmawati, Ahmad Syauqy ${ }^{*}$ \\ Program Studi Ilmu Gizi Fakultas Kedokteran Universitas Diponegoro \\ J1.Dr.Sutomo No.18, Semarang, Telp (024) 8453708, Email : gizifk@ undip.ac.id
}

\begin{abstract}
Background: Food intake of patients with Chronic Kidney Disease (CKD) tend to be low. One of the factors that influence food intake is nutrition knowledge. The purpose of this study was to identify the relationship of nutrition knowledge with intake of energy, protein, phosphorus, and potassium in CKD patients with regular hemodialysis in RSUD Tugurejo Semarang.

Methods: This study was a crossesctional study. Subjects were CKD patients with regular hemodialysis. The number of subjects were 27 patients, taken by quota sampling. Data of age, level of education, occupation, history of nausea/vomiting, old undergoing hemodialysis, and nutrition knowledge were obtained from questionnaires. Data of energy, protein, phosphorus, and potassium intake were measured by food record for 3 days. Data were analyzed by Pearson Test and Spearman.

Results: Subjects consisted of 59,3\% men, subject's education was 55,6\% high school, 33.3\% of subjects work as private employees, and $96.3 \%$ of subjects had no history of nausea/vomiting. This study also found that 96,3\% of subjects had not good energy and protein intake, 55,6\% of subjects had a good intake of potassium, 88,8\% of subjects had not good of phosphorus intake, and 92,6\% of subjects had not good of nutrition knowledge.There was a correlation between nutrition knowledge and protein intake $(p=0,026)$. There was no correlation between nutrition knowledge and energy intake $(p=0,871)$, phosphorus intake $(p=0,250)$, and potassium intake $(p=0,901)$

Conclusion: Nutritional knowledge have correlation with protein intake, but not correlate with intake of energy, phosphorus, and potassium.
\end{abstract}

Keywords: Nutrition knowledge; energy; protein; phosphorus; potassium; chronic kidney disease

\section{ABSTRAK}

Latar belakang: Asupan makan pasien Penyakit Ginjal Kronik (PGK) cenderung rendah. Salah satu faktor yang mempengaruhi asupan makan adalah pengetahuan gizi. Tujuan penelitian ini adalah untuk mengetahui hubungan pengetahuan gizi dengan asupan energi, protein, phosphor, dan kalium pasien PGK dengan HD rutin di RSUD Tugurejo Semarang.

Metode: Penelitian ini merupakan penelitian crossectional. Subjek penelitian adalah pasien PGK dengan hemodialisis rutin. Jumlah subjek sebanyak 27 pasien, yang diambil secara quota sampling. Data umur, tingkat pendidikan, pekerjaan, riwayat mual/muntah, lama hemodialisis dan pengetahuan gizi diperoleh dari kuesioner. Data asupan energi, protein, phosphor, dan kalium diukur dengan food record 3 hari. Analisis data menggunakan uji Pearson dan Spearman.

Hasil: Subjek, terdiri atas 59,3\% laki-laki, pendidikan subjek 55,6\% SMA, 33,3\% subjek bekerja sebagai pegawai swasta, dan 96,3\% subjek tidak mempunyai riwayat mual/muntah. Sebanyak 96,3\% subjek asupan energi dan proteinnya tidak baik, 55,6\% asupan kaliumnya baik, 88,8\% asupan phospornya tidak baik, dan 92,6\% subjek mempunyai pengetahuan gizi yang rendah. Ada hubungan antara pengetahuan gizi dengan asupan protein $(p=0,026)$. Tidak ada hubungan antara pengetahuan gizi dengan asupan energi $(p=0,871)$, asupan phosphor ( $p=0,250)$, dan asupan kalium $(p=0,901)$.

Kesimpulan: Pengetahuan gizi berhubungan dengan asupan protein, tapi tidak berhubungan dengan asupan energi, phosphor, dan kalium

Kata kunci: Pengetahuan gizi; energi; protein; phosphor; kalium; penyakit ginjal kronik

\section{PENDAHULUAN}

Penyakit Ginjal Kronik (PGK) merupakan suatu proses patofisiologis yang mengakibatkan penurunan fungsi ginjal yang berlangsung lebih dari 3 bulan dengan atau tanpa penurunan Laju Filtrasi Glomerular (LFG) . ${ }^{1}$ Angka kejadian PGK meningkat setiap tahun. Pada tahun 2000 penderita
PGK di dunia yang menjalani terapi penggantian ginjal sebanyak dua juta orang. Di Indonesia perkiraan insiden PGK antara 100 - 150 per satu juta penduduk dengan prevalensi $200-250$ per satu juta penduduk. ${ }^{2}$

Menurunnya fungsi ginjal mengakibatkan berkurangnya kemampuan ginjal dalam menyaring 
darah, sehingga zat- zat sisa metabolisme yang seharusnya dikeluarkan melalui urin menumpuk di dalam darah. Semakin banyak zat sisa metabolisme yang tidak terbuang, maka akan semakin berat kerja ginjal.

PGK tahap 5 merupakan gagal ginjal tahap akhir, yang mengharuskan pasien memerlukan hemodialisis (HD) atau transplantasi ginjal. ${ }^{3} \mathrm{HD}$ dilakukan untuk mengeluarkan zat- zat toksik, seperti ureum dan kreatinin, serta mengeluarkan kelebihan cairan. Namun dalam proses HD juga membuang zat- zat gizi yang masih diperlukan tubuh, diantaranya protein, glukosa, dan vitamin larut air. Kehilangan zat - zat gizi ini apabila tidak ditanggulangi dengan benar dapat menyebabkan gangguan status gizi.

Asupan makan pasien PGK biasanya rendah, hal ini dikarenakan menurunnya nafsu makan, timbulnya rasa mual dan diikuti oleh muntah, yang dapat berpengaruh terhadap penurunan berat badan penderita. $^{2}$

The National Kidney Foundation Kidney Disease Outcomes Quality Initiative (NKFK/DOQI) merekomendasikan pemberian asupan tinggi protein untuk pasien dialisis. Namun, bahan makanan yang tinggi protein merupakan sumber phosphor yang tinggi. Kadar serum phosphor yang melebihi $5,5 \mathrm{mg} / \mathrm{dL}$ dapat meningkatkan mortalitas kardiovaskuler. ${ }^{4}$ Terdapat hubungan antara asupan protein, asupan phosphor, dan rasio phosphor-protein dengan kadar phosphor darah pada pasien PGK dengan HD. ${ }^{5}$

Kebiasaan makan dan pengetahuan tentang penyakit yang dideritanya serta diet yang harus dijalani sangat penting untuk pasien PGK agar tidak terjadi malnutrisi. Selain itu juga untuk mencegah komplikasi dan tidak memperparah komplikasi yang sudah terjadi. Penelitian yang telah dilakukan menyebutkan bahwa pengetahuan gizi pasien HD secara umum sudah baik, namun masih rendah untuk pengetahuan tentang phosphor dibandingkan dengan zat gizi lain seperti protein, natrium, dan kalium. ${ }^{6}$

Pengetahuan merupakan hal yang sangat penting dalam membentuk tindakan seseorang. Salah satu bentuk tindakan dari hasil pengetahuan pasien PGK adalah asupan makan. Penelitian yang sudah pernah dilakukan menyebutkan bahwa ada hubungan yang signifikan antara pengetahuan tentang asupan cairan dengan penambahan berat badan.

Berdasarkan gambaran tersebut Penulis tertarik untuk mengetahui hubungan pengetahuan gizi dengan asupan energi, protein, phosphor, dan kalium yang pasien PGK dengan HD rutin. Tujuan penelitian ini yaitu untuk mengetahui hubungan pengetahuan gizi dengan asupan energi, protein, phosphor, dan kalium pasien PGK dengan HD rutin di RSUD Tugurejo Semarang.

\section{METODE PENELITIAN}

Penelitian ini dilakukan di RSUD Tugureo Semarang, pada bulan November 2013. Penelitian ini merupakan penelitian observasional analitik, dengan menggunakan rancangan Cros sectional, dan termasuk lingkup gizi klinik.

Subyek penelitian ini adalah pasien PGK dengan HD rutin. Kriteria inklusi pada penelitian ini adalah : bersedia menjadi responden, pasien PGK dengan HD rutin 2 kali seminggu, tidak rawat inap, sudah menjalani HD rutin minimal 1 bulan, sedangkan kriteria eksklusi : pasien tidak melakukan HD kedua setelah dilakukan wawancara. Pemilihan sampel dalam penelitian ini dengan menggunakan Non-probability sampling, yaitu quota sampling. Jumlah sampel dalam penelitian ini sebanyak 27 orang.

Variabel bebas dalam penelitian ini adalah pengetahuan gizi, sedangkan variabel terikatnya adalah asupan energi, protein, phosphor, dan kalium. Data yang dikumpulkan dalam penelitian ini, adalah data karakteristik responden, pengetahuan gizi dan asupan energi, protein, phosphor, dan kalium. Instrumen yang digunakan adalah kuesioner, formulir food record, timbangan berat badan (analitik), dan pengukur tinggi badan (microtoa).

Karakteristik responden meliputi nama, umur, jenis kelamin, kondisi mual/muntah, pendidikan, pekerjaan, lama menjalani hemodialisa, lama sakit, dan hasil laboratorium yang diperoleh dari kuesioner dan data rekam medis responden. Data tentang pengetahuan gizi diperoleh dari wawancara dengan menggunakan kuesioner pengetahuan gizi. Asupan energi, protein, phosphor, dan kalium merupakan rata-rata asupan dari makanan yang dikonsumsi selama 3 hari yang diperoleh dengan menggunakan metode food record. Hasil dari food record kemudian diproses dengan menggunakan program Food Processor 3, dan dikonversikan dalam bentuk gram per kilogram berat badan per hari untuk energi dan protein, miligram per kilogram berat badan per hari untuk kalium, dan miligram per hari untuk phosphor kemudian dibandingkan dengan kebutuhan per orang per hari. Asupan energi dikategorikan menjadi asupan energi adekuat jika $30-35 \mathrm{~g} / \mathrm{kgBBI} / \mathrm{hari}$, dan kurang jika kurang dari $30 \mathrm{~g} / \mathrm{kgBBI} / \mathrm{hari}$, asupan 
protein adekuat jika $1-1,2 \mathrm{~g} / \mathrm{kgBBI} / \mathrm{hari}$, dan kurang jika kurang dari $1 \mathrm{~g} / \mathrm{kgBBI} / \mathrm{hari}$, asupan phosphor adekuat jika $800-1000 \mathrm{mg} /$ hari dan kurang jika kurang dari $800 \mathrm{mg} / \mathrm{hari}$, asupan kalium adekuat jika $8-17 \mathrm{mg} / \mathrm{kgBB} / \mathrm{hari}$ dan kurang jika kurang dari $8 \mathrm{mg} / \mathrm{kgBB} /$ hari. $^{8}$ Pengetahuan gizi adalah pengetahuan responden mengenai energi, protein, phosphor, dan kalium yang diperoleh melalui kuesioner pengetahuan gizi yang terdiri dari 15 pertanyaan. Pertanyaan merupakan pilihan jawaban ya dan tidak dengan penilaian memberikan nilai 0 untuk jawaban tidak dan nilai 1 untuk jawaban ya. Tingkat pengetahuan diperoleh dengan cara skor pengetahuan dengan jawaban ya dibandingkan dengan total jawaban, kemudian dikelompokkan

menjadi baik apabila lebih dari $75 \%$, cukup 56 $75 \%$ dan kurang apabila kurang dari $56 \%{ }^{9}$

Analisis data menggunakan program komputer. Analisis univariat digunakan untuk mendiskripsikan data karakteristik subyek, asupan energi, protein, phosphor, dan kalium, serta pengetahuan gizi. Uji statistik yang digunakan adalah uji korelasi Pearson untuk mengetahui hubungan pengetahuan gizi dengan asupan protein, phosphor dan kalium karena data berdistribusi normal saat dilakukan uji normalitas data. Untuk mengetahui hubungan pengetahuan gizi dengan asupan energi digunakan uji korelasi Spearman karena data berdistribusi tidak normal ketika dilakukan uji normalitas data.

\section{HASIL PENELTIAN \\ Karakteristik Responden}

Tabel 1. Distribusi frekuensi umur, jenis kelamin, tingkat pendidikan, pekerjaan, kondisi mual muntah, lama HD, lama sakit, konseling gizi, dan hasil laboratorium responden

\begin{tabular}{|c|c|c|}
\hline $\begin{array}{r}\text { Variabel } \\
\end{array}$ & $\mathbf{N}$ & $\%$ \\
\hline $\begin{array}{l}\text { 1. Umur responden } \\
-21-40 \text { th } \\
-41-60 \text { th } \\
->40 \text { th }\end{array}$ & $\begin{array}{c}7 \\
18 \\
2\end{array}$ & $\begin{array}{c}25,9 \\
66,7 \\
7,4\end{array}$ \\
\hline $\begin{array}{l}\text { 2. Jenis kelamin responden } \\
\text { - Laki-laki } \\
\text { - Perempuan } \\
\end{array}$ & $\begin{array}{l}16 \\
11 \\
\end{array}$ & $\begin{array}{l}59,3 \\
40,7 \\
\end{array}$ \\
\hline $\begin{array}{l}\text { 3. Tingkat pendidikan responden } \\
\text { - Tidak sekolah } \\
\text { - SD/sederajat } \\
\text { - SMP/sederajat } \\
\text { - SMA/sederajat } \\
\text { - Perguruan Tinggi/akademi }\end{array}$ & $\begin{array}{c}1 \\
4 \\
3 \\
15 \\
4\end{array}$ & $\begin{array}{c}3,7 \\
14,8 \\
11,1 \\
55,6 \\
14,8\end{array}$ \\
\hline $\begin{array}{l}\text { 4. Pekerjaan responden } \\
\text { - Tidak bekerja } \\
\text { - Ibu rumah tangga } \\
\text { - Pegawai negeri } \\
\text { - Pegawai swasta } \\
\text { - Wiraswasta } \\
\end{array}$ & $\begin{array}{l}4 \\
7 \\
2 \\
9 \\
5 \\
\end{array}$ & $\begin{array}{r}14,8 \\
25,9 \\
7,4 \\
33,3 \\
18,5 \\
\end{array}$ \\
\hline $\begin{array}{l}\text { 5. Kondisi mual muntah } \\
\text { - Ya } \\
\text { - Tidak } \\
\end{array}$ & $\begin{array}{c}1 \\
26 \\
\end{array}$ & $\begin{array}{r}3,7 \\
96,3 \\
\end{array}$ \\
\hline $\begin{array}{ll}6 . & \text { Lama HD } \\
- & \leq 12 \mathrm{bln} \\
->12 \mathrm{bln}\end{array}$ & $\begin{array}{c}21 \\
6 \\
\end{array}$ & $\begin{array}{l}77,8 \\
22,2 \\
\end{array}$ \\
\hline $\begin{array}{l}\text { 7. Lama sakit } \\
-\leq 12 \mathrm{bln} \\
->12 \mathrm{bln} \\
\end{array}$ & $\begin{array}{l}17 \\
10 \\
\end{array}$ & $\begin{array}{l}62,9 \\
37,1 \\
\end{array}$ \\
\hline $\begin{array}{l}\text { 8. Konseling gizi } \\
\text { - pernah } \\
\text { - tidak pernah }\end{array}$ & $\begin{array}{c}1 \\
26\end{array}$ & $\begin{array}{r}3,7 \\
96,3\end{array}$ \\
\hline
\end{tabular}

Usia responden pada penelitian ini antara $30-$ 62 tahun, dan paling banyak pada usia $41-60$ tahun, yaitu sebesar $66,7 \%$. Lama responden menjalani HD antara $2-60$ bulan. Lama sakit antara 5 - 66 bulan. Sebanyak 59,3\% responden berjenis kelamin laki-laki dan $40,7 \%$ berjenis 
kelamin perempuan. Terdapat $3,7 \%$ responden yang tidak bersekolah dan masih merasakan mual.

Tabel 2. Distribusi frekuensi kadar ureum, kreatinin, dan hemoglobin

\begin{tabular}{lcccc}
\hline \multicolumn{1}{c}{ Variabel } & n & \% & mean & Sd \\
\hline Kadar ureum & 3 & 11,1 & 79,67 & 22,319 \\
Normal 10,0-50,0 mg/dL & 24 & 88,9 & & \\
Tinggi $>50,0 \mathrm{mg} / \mathrm{dL}$ & 1 & 3,7 & 7,37 & 3,94 \\
\hline Kadar kreatinin & 26 & 96,3 & & \\
$\begin{array}{l}\text { Normal 0,7 }-1,1 \mathrm{mg} / \mathrm{dL} \\
\text { Tinggi }>1,1 \mathrm{mg} / \mathrm{dL}\end{array}$ & 1 & 3,7 & 9,0 & 1,17 \\
\hline Kadar hemoglobin & 26 & 96,3 & & \\
$\begin{array}{l}\text { Anemia }<11 \mathrm{~g} / \mathrm{dL} \\
\text { Tidak anemia } \geq 11 \mathrm{~g} / \mathrm{dL}\end{array}$ & & &
\end{tabular}

Gambaran pengetahuan gizi dengan asupan energi, protein, phosphor, dan kalium

Pengetahuan gizi responden sebanyak 66,7\% (18 orang) termasuk masih kurang, dan hanya 7,4 $\%$ (2 orang) responden yang pengetahuan gizinya baik.

Asupan energi dan asupan protein responden sebanyak 96,3\% ( 26 orang) masih kurang. Hanya
$3,7 \%$ (1 orang) yang asupan energi dan proteinnya adekuat. Asupan kalium responden sebanyak $55,6 \%$ ( 15 orang) adekuat, sedangkan asupan phosphor sebanyak $88,8 \%$ ( 24 orang) masih kurang.

Asupan energi, protein, phosphor, kalium dan pengetahuan gizi dapat dilihat pada tabel 3 .

Tabel 3. Distribusi frekuensi asupan energi, protein, phospor, kalium, dan tingkat pengetahuan

\begin{tabular}{lcc}
\hline \multicolumn{1}{c}{ Variabel } & N & $\%$ \\
\hline 1. Tingkat asupan energi & 1 & 3,7 \\
- Adekuat (30-35 g/kg BBI/hari) & 26 & 96,3 \\
- Kurang (<30g/kgBBI/hari) & & \\
& & 3,7 \\
\hline 2. Tingkat asupan protein & 1 & 96,3 \\
- Adekuat (1-1,2 g/kg BBI/hari) & 26 & \\
- Kurang (<1 g/kgBBI/hari) & & 55,6 \\
\hline 3. Tingkat asupan kalium & 15 & 44,4 \\
- Adekuat (8-17 mg/kg BB/hari) & 12 & \\
- Kurang (<8 mg/kgBB/hari) & & 11,1 \\
& & 88,9 \\
\hline 4. Tingkat asupan phosphor & 3 & 66,7 \\
- Adekuat (800-1000mg/hari) & 24 & 25,9 \\
- Kurang (<800 mg/hari) & & 7,4 \\
\hline 5. Tingkat pengetahuan & 18 & \\
- Kurang (<56\%) & 7 & \\
- Cukup (56-75\%) & 2 & \\
- Baik (>75\%) & & \\
\hline
\end{tabular}

Hubungan pengetahuan gizi dengan asupan energi, protein, phosphor, dan kalium

Tabel 4. Pengetahuan gizi dengan asupan energi, protein, phosphor, dan kalium

\begin{tabular}{|c|c|c|c|c|c|c|}
\hline \multirow{3}{*}{ Variabel } & \multicolumn{4}{|c|}{ Pengetahuan } & \multirow{2}{*}{\multicolumn{2}{|c|}{ Kurang }} \\
\hline & \multicolumn{2}{|c|}{ Baik } & \multicolumn{2}{|c|}{ Cukup } & & \\
\hline & $\mathbf{N}$ & $\%$ & $\mathbf{n}$ & $\%$ & $\mathbf{N}$ & $\%$ \\
\hline \multicolumn{7}{|l|}{ Asupan Energi } \\
\hline - adekuat & 1 & 50 & 0 & 0 & 0 & 0 \\
\hline - kurang & 1 & 50 & 7 & 100 & 18 & 100 \\
\hline Total & 2 & 100 & 7 & 100 & 18 & 100 \\
\hline
\end{tabular}




\begin{tabular}{lcccccc}
\hline - adekuat & 0 & 0 & 0 & 0 & 1 & 5,6 \\
- kurang & 2 & 100 & 7 & 100 & 17 & 94,4 \\
\hline Total & 2 & 100 & 7 & 100 & 18 & 100 \\
\hline Asupan Phosphor & & & & & & \\
- adekuat & 1 & 50 & 0 & 0 & 2 & 11,1 \\
- kurang & 1 & 50 & 7 & 100 & 16 & 88,9 \\
\hline Total & 2 & 100 & 7 & 100 & 18 & 100 \\
\hline Asupan Kalium & & & & & & \\
- adekuat & 2 & 100 & 4 & 57,2 & 9 & 50 \\
- kurang & 0 & 0 & 3 & 42,8 & 9 & 50 \\
\hline Total & 2 & 100 & 7 & 100 & 18 & 100 \\
\hline
\end{tabular}

Hanya ada satu orang responden yang asupan energi dan phosphornya adekuat dengan pengetahuan gizi yang baik. Ada dua orang

responden dengan asupan kalium yang adekuat dan pengetahuan gizinya baik.

Tabel 5. Uji hubungan pengetahuan gizi dengan asupan energi, protein, phosphor, dan kalium

\begin{tabular}{lcc}
\hline \multicolumn{1}{c}{ Jenis Hubungan } & $\mathrm{R}$ & $\mathrm{p}$ \\
\hline $\begin{array}{l}\text { Pengetahuan gizi dengan } \\
\text { asupan energi }\end{array}$ & 0,033 & $0,871^{*}$ \\
\hline $\begin{array}{l}\text { Pengetahuan gizi dengan } \\
\text { asupan protein }\end{array}$ & 0,428 & $0,026^{* *}$ \\
\hline $\begin{array}{l}\text { Pengetahuan gizi dengan } \\
\text { asupan phosphor }\end{array}$ & 0,229 & $0,250^{*}$ \\
\hline $\begin{array}{l}\text { Pengetahuan gizi dengan } \\
\text { asupan kalium }\end{array}$ & $-0,025$ & $0,901^{*}$ \\
\hline
\end{tabular}

*uji korelasi pearson

**uji korelasi spearman

Tabel 5 merupakan hasil uji dengan menggunakan uji Pearson untuk hubungan pengetahuan gizi dengan protein, phosphor, dan kalium, sedangkan uji Spearman, dilakukan untuk hubungan pengetahuan gizi dengan asupan energi. Kedua uji tersebut menunjukkan ada hubungan antara pengetahuan gizi dengan asupan protein, dan tidak ada hubungan pengetahuan gizi dengan asupan energi, phosphor, dan kalium.

\section{PEMBAHASAN}

Hasil penelitian didapatkan data, mayoritas responden berumur antara $41-60$ tahun dan berjenis kelamin laki-laki. Secara umum kejadian PGK lebih besar terjadi pada laki-laki daripada perempuan. ${ }^{10}$ Penurunan fungsi ginjal terjadi pada usia 40 tahun. Penambahan usia menyebabkan menurunnya fungsi ginjal untuk melakukan penyaringan dalam tubuh.

Tingkat pendidikan responden sebagian besar berpendidikan SMA/sederajat, yaitu sebanyak $55, \%$, sedangkan yang berpendidikan perguruan tinggi/akademi hanya $14,8 \%$. Tingkat pendidikan merupakan salah satu faktor yang mempengaruhi pengetahuan. ${ }^{11}$
Pekerjaan responden paling banyak sebagai pegawai swasta, yaitu sebanyak 33,3\%. Pekerjaan dimaksudkan untuk mendapatkan penghasilan. Penghasilan yang cukup, akan lebih memudahkan untuk memenuhi kebutuhan primer maupun sekunder keluarga. ${ }^{12}$

Pada penelitian ini, masih didapatkan responden yang merasakan mual, sebanyak 1 orang. Hal ini bisa saja disebabkan adanya uremia (penumpukan urea dalam darah) yang mengakibatkan menurunnya nafsu makan, timbulnya rasa mual dan diikuti oleh muntah. ${ }^{3}$

Responden mayoritas menjalani HD $\leq 12$ bulan, yaitu sebanyak 77,8\%. Lama sakit juga dapat memperparah kerusakan ginjal. Sebanyak $62,9 \%$ responden diketahui sakit $\leq 12$ bulan. Sebagian besar responden menyatakan tidak tahu kalau menderita PGK. Responden hanya merasa tidak enak badan, tidak nafsu makan, lemas, mualmual kadang disertai dengan muntah. Semua responden sudah pernah dirawat di rumah sakit. Responden sudah pernah dirawat di rumah sakit 24 kali.

Hanya 1 responden yang pernah mendapatkan konseling gizi setelah menjalani HD rutin. Konseling gizi merupakan salah satu upaya untuk 
meningkatkan `pengetahuan gizi responden. ${ }^{13}$ Ada beberapa responden menyatakan sudah pernah mendapatkan konseling gizi pada awal diketahui responden menderita PGK, namun belum pernah mendapatkan konseling gizi setelah menjalani HD rutin. Kebutuhan gizi pasien PGK dengan HD berbeda dengan pasein PGK sebelum HD. ${ }^{8}$

Hasil uji statistik didapatkan hasil tidak ada hubungan antara pengetahuan gizi dengan energi $(p>0,05 ; r=0,033)$, phosphor $(p>0,05 ; r=0,229)$, dan kalium $p>0,05 ; r=-0,025)$. Hasil wawancara dengan kuesioner tentang pengertian energi dan makanan sumber energi, serta akibat kurang asupan energi sebagian besar responden dapat menjawab dan menjelaskan, namun pada kenyataannya asupan responden masih kurang dari kebutuhan. Hasil wawancara dengan kuesioner tentang phosphor dan makanan sumber phosphor hanya ada tiga orang responden yang dapat menjawab dan menjelaskannya. Hasil wawancara dengan kuesioner tentang kalium, sebagian besar responden dapat menjawab dan menjelaskan. Kalium lebih dikenal oleh responden dibandingkan dengan phosphor.

Hasil uji statistik, didapatkan hasil ada hubungan antara pengetahuan gizi dengan asupan protein $(\mathrm{p}<0,005 ; \mathrm{r}=0,428)$. Responden lebih banyak mengkonsumsi protein hewani dibandingkan dengan protein nabati dan ada beberapa responden yang tidak pernah mengkonsumsi protein nabati karena informasi yang diperoleh sebelumnya. Hasil penelitian di RSUP dr. Sardjito diketahui rata-rata asupan protein pasien PGK dengan HD masih dibawah kebutuhan. Rendahnya asupan energi dan protein pasien PGK dengan HD rutin dipengaruhi juga oleh faktor sosial ekonomi (depresi, ketidaktahuan, dan kemiskinan). Proses HD yang juga membuang zat-zat gizi yang masih diperlukan tubuh, seperti protein, glukosa, dan vitamin larut air dapat mengakibatkan asupan energi dan protein yang tidak adekuat. ${ }^{14}$

Terdapat 96,3\% responden asupan energi dan proteinnya kurang. Sebagian besar responden menyatakan takut untuk mengkonsumsi makanan dalam jumlah yang lebih banyak dan tidak tahu bahwa kebutuhannya menjadi meningkat apabila menjalani HD rutin. Pada saat responden mulai menjalani HD, responden mengeluh mual dan kadang disertai muntah, sehingga asupannya sedikit. Setelah memasuki bulan kedua, responden menyatakan sudah tidak mual lagi, walaupun saat ini masih ada satu orang responden yang kadang merasakan mual. Kebiasaan makan responden sebelum melakukan HD rutin cenderung tidah bisa diubah, sehingga asupannya tetap sedikit. Hasil dari wawancara tentang pengaturan makan, $100 \%$ responden menjawab sudah mengatur makanan yang mereka konsumsi, yang dapat diartikan semua responden membatasi asupan makannya. Sebagian besar responden hanya mengkonsumsi nasi sebanyak satu centong nasi tiap kali makan, bahkan ada pula responden yang hanya berani mengkonsumsi satu sendok nasi. Selain nasi, beberapa responden juga mengkonsumsi roti, singkong, dan kentang. Sumber protein responden sebagian besar didapat dari telur, ayam, tahu, dan tempe, namun ada juga responden yang sama sekali tidak mengkonsumsi protein nabati, karena informasi yang diterima mengatakan untuk tidak mengkonsumsi protein nabati. Hampir semua responden menyatakan tidak berani mengkonsumsi daging sapi. Mereka berpendapat apabila mengkonsumsi daging sapi, maka akan mempengaruhi hasil pemeriksaan laboratorium. Asupan energi dan protein yang kurang dan dalam jangka waktu yang lama, dapat mengakibatkan malnutrisi. ${ }^{2}$ Berdasarkan sebuah penelitian klinik menunjukkan bahwa pasien HD yang mengkonsumsi energi dan protein dibawah nilai yang dianjurkan, yaitu asupan protein dibawah 0,8 $\mathrm{gr} / \mathrm{kgBB} / \mathrm{hr}$ dan asupan energi dibawah 25 $\mathrm{kkal} / \mathrm{kgBB} / \mathrm{hr}$, dapat meningkatkan risiko morbiditas dan mortalitas. ${ }^{15}$

Sebanyak 88,9\% responden tingkat asupan phosphornya masih kurang. Hasil dari wawancara yang berkaitan dengan phosphor, hanya 3 orang responden yang dapat menjawabnya. Hanya satu orang responden yang sudah mengetahui akibat dari kelebihan asupan phosphor. Responden menyatakan sudah pernah melakukan pemeriksaan kadar phosphornya, yang pada saat itu diketahui kadar phosphor dalam darahnya sebanyak $10 \mathrm{mg} / \mathrm{dl}$. Responden kemudian mengontrol kadar phosphor dalam darahnya dengan obat pengikat phosphor. Terakhir melakukan pemeriksaan kadar phosphor pada bulan Agustus tahun 2012, dan hasilnya sebesar 6,5mg/dl. Tingkat asupan phosphor responden yang masih kurang berkaitan juga dengan asupan proteinnya. Asupan phosphor yang kurang dalam jangka waktu yang lama dapat menyebabkan kadar phosphor dalam darah menjadi rendah. Bahan makanan yang tinggi protein merupakan sumber phosphor yang tinggi pula. $^{4}$

Sebanyak 55,6\% responden tingkat asupan kaliumnya adekuat. Hasil wawancara tentang kalium, sebagian besar responden tidak dapat 
menjawab dan menjelaskannya. Responden tidak mengetahui jenis makanan sumber kalium. Responden yang dapat menjawab kuesioner hanya bisa menjelaskan kalium hanya terdapat pada buah-buahan, tetapi tidak mengetahui akibat dari kelebihan kalium. Masih ada responden yang mengkonsumsi bahan makanan tinggi kalium, seperti singkong, kentang, tomat, dan air kelapa muda. Asupan kalium yang berlebihan dalam waktu yang lama dapat menyebabkan tingginya kadar kalium dalam darah. Apabila kadar kalium dalam darah tinggi atau hiperkalemia, dapat menyebabkan irama jantung menjadi tidak teratur, terutama pada penderita jantung. ${ }^{16}$

Pemeriksaan laboratorium dilakukan dua minggu sekali, meliputi pemeriksaan ureum, kreatinin, dan hemoglobin (Hb). Hasil laboratorium ureum dan kreatinin hampir semua responden masih tinggi dan $\mathrm{Hb}$ masih rendah. Sebanyak 88,9\% responden kadar ureum dalam darahnya masih tinggi, yaitu lebih dari $50 \mathrm{mg} / \mathrm{dL}$. Sebanyak 96,3\% responden kadar kreatininnya masih tinggi, yaitu lebih dari $1,1 \mathrm{mg} / \mathrm{dL}$. Kadar ureum dan kreatinin dalam darah dipengaruhi oleh asupan protein. Asupan protein yang tinggi akan menyebabkan tingginya kadar ureum dan kreatinin. Namun dalam penelitian ini, asupan protein responden masih kurang sedangkan kadar ureum dan kreatininnya tinggi. Ureum dan kreatinin merupakan produk akhir dari metabolisme protein yang harus dikeluarkan dari tubuh. Sebagian besar responden menyatakan susah buang air kecil, sehingga ureum dan kreatinin yang seharusnya dikeluarkan melalui urin menjadi menumpuk dalam darah. Tingginya kadar ureum dan kreatinin dalam darah yang tidak bisa dikeluarkan karena fungsi ginjal yang menurun dapat menjadi toksik di dalam tubuh. Rendahnya kadar $\mathrm{Hb}$ responden dipengaruhi asupan makan responden yang tidak adekuat. Selain itu juga dipengaruhi tingginya kadar ureum dalam darah. Kadar ureum yang tinggi dapat menginaktifkan eritropoietin atau menekan respon sumsum tulang terhadap eritropoietin untuk menghasilkan sel darah merah. ${ }^{17}$

\section{SIMPULAN}

Terdapat hubungan antara pengetahuan gizi dengan asupan protein. Tidak terdapat hubungan antara pengetahuan gizi dengan asupan energi, phosphor, dan kalium.

\section{DAFTAR PUSTAKA}

1. Perhimpunan Nefrologi Indonesia. Konsensus Dialisis: PERNEFRI, 2003, hal.13

2. Firmansyah, A.M. Usaha Memperlambat Perburukan Penyakit Ginjal Kronik Ke Penyakit Ginjal Stadium Akhir. Cermin dunia Kedokteran, ISSN : 0125 -913/x/176/vol. 5/no. 3/April 2010.

3. AsDI. PERNEFRI. Sehat dengan Penyakit Ginjal Kronik 2009, hal 4 - 15

4. Malmberg K. Prospective Randomized Study of Intensive Insulin Treatment an Long Term Survival Atteracute Myocardial Infarction in Patient with DM. DIGAMI (DM, Insulin Glucose Infusion in Acute Myiocardial Infarction). Study Grup, BMJ 1977; 314, 1512 - 15

5. Syauqy,A. Hubungan Asupan Protein, Asupan Fosfor, dan Rasio Fosfor-Protein dengan Kadar Fosfor Darah pada Pasien Penyakit Ginjal Kronik dengan Hemodialisis Rutin di Yayasan Ginjal Diatrans Indonesia, Jurnal Gizi Klinik. Vol.09.No.2.Oktober 2012

6. Cupisty, et al. Nutritional Knowledge in Hemodialysis Patient's and Nurses: Focus on Phosphorus. Jurnal of Renal Nutrition. November 2012

7. Susti, N. Hubungan Pengetahuan tentang Asupan Cairan dan Cara Pengendalian Asupan Cairan terhadap Penambahan Berat Badan. Universitas Riau. 2012

8. Perhimpunan Nefrologi Indonesia. Konsensus Dialisis: PERNEFRI, 2011, hal.17

9. Arikunto, Suharsini. Prosedur Penelitian Suatu Pendekatan Praktik. Rineka cipta. Jakarta : 2006

10. Price SA, Wilson LM, alih bahasa Huriwati Hartanto, Patofisiologi Konsep Klinis Proses-proses Penyakit Edisi VI volume 2, Buku KedokteranEGC, 2005, hal. 914-16.

11. Mubarok, Wahit Iqbal, dkk. Promosi Kesehatan. Sebuah Pengantar Proses Belajar Mengajar dalam Pendidikan. Yogyakarta. Graha Ilmu. 2007, hal 30.

12. Notoatmodjo, S. Pendidikan dan Perilaku Kesehatan. Jakarta : Rineka Cipta. 2003

13. PERSAGI. Penuntun Konseling Gizi. Jakarta : PT. Abadi; 2011. Hlm 12

14. Susetyowati. Peranan Konsultasi Gizi Berkelanjutan Terhadap Kadar Albumin Penderita Penyakit Ginjal Kronik dengan Hemodialisis di RS dr. Sardjito Yogyakarta. Berkala Kesehatan Klinik. Vol.XI.No.1. 2005

15. Bellizi ,et al. Daily nutrient intake represents a modifiable determinant of nutritional status in chronic haemodialysis patients. Nephrol Dial Transplant.2003.18:1874-81.

16. The National Kidney Foundation. Pottasium and Your CKD Diet. 2013. www.kidney.or

17. Guyton,Arthur Hall. Buku Ajar Fisiologi Kedokteran Edisi 11. Jakarta. Penerbit Buku Kedokteran.EGC.2007.hal.307-365 